\title{
Gehiegizko pisua 0-7 urteko adineko umeengan. Arrisku-faktoreak
}

\section{The excess weight of 0 to 7 year-old children - risk factors}

\author{
Iratxe Escudero Otxandorena ${ }^{1}$, Eva Pereda-Pereda ${ }^{1,3}$, Izaro Babarro Velez ${ }^{1,2,3}$, Juan J. Aurrekoetxea \\ Agirre ${ }^{1,2,3}$ \\ ${ }^{1}$ Euskal Herriko Unibertsitatea, UPV/EHU \\ ${ }^{2}$ Osasun Saila. Eusko Jaurlaritza.Donostia \\ ${ }^{3}$ Biodonostia Osasun Ikerketa Institutua.Donostia \\ jj.aurreko@gmail.com
}

\section{Laburpena}

Ikerketa honen helburua Gipuzkoako umeen pisuaren joera jaiotzetik 7 urtetara bitartean aztertzea zen, gurasoen ezaugarri soziodemografikoen eta antropometrikoen eragina aztertuz. INMA ikerketa multizentriko prospektiboko Gipuzkoako 450 ama-haur bikotek osatu zuten lagina. Jaiotzean, 1., 4. eta 7. urteetan neurtutako gorputz-masaren indizean (GMI) oinarrituz, jaiotzean $\geq 90$ eko pertzentilean eta gainerako adinetan $\geq 85$ eko pertzentilean izatea gehiegizko pisua (GP) bezala definitu zen, gainpisua eta obesitatea barne hartuz. Umearen eta gurasoen aldagai antropometrikoak, edoskitze mota, 4. urtean egindako elikagai-inkesta, gurasoen tabako-kontsumoa haurdunaldi garaian eta aldagai sozioekonomikoak aztertu ziren. Erregresio logistikoaren bitartez, aldagai bakoitzaren eragin zuzena ikertu zen. Jaiotzean umeen $\% 11 \mathrm{k}, 1$. urtean $\% 49 \mathrm{k}$, 4. urtean $\% 36 \mathrm{k}$ eta 7 . urtean \% 38k GPa zuten. Jaiotzean haurdunaldi-adinerako handia izatea eta lehen urtean pisu-hazkundea azkarra edukitzea ondorengo urteetako GParekin lotzen ziren. Neskek 4 . eta 7. urteetan mutilek baino GP-arrisku handiagoa zuten. Edoskitzeak ez zuen GParekin lotura esanguratsurik adierazi. GPa 4. urtean proteinen eta karbohidratoen eta 7. urtean karbohidratoen eta gantz aseen zein poliasegabeen kontsumoarekin areagotzen zen. Paritateak jaiotzako GPa areagotzen zuen. Gurasoen GMla umeen GParekin lotzen zen adin guztietan. Aitaren ikasketa-maila baxua jaiotzako GParekin eta ama atzerritarra izatea umeen 4. urteko GParekin erlazionatzen ziren. Aita erretzaileen umeek GPa edukitzeko arrisku handiagoa zuten 4. eta 7. urteetan, baina amaren tabako-kontsumoak ez zuen arriskua areagotzen. Lan honetan jaiotza eta 7 urte bitarteko GParen prebalentzia oso altua dela aurkitu da. Osasun-arazo garrantzitsu horri aurre egiteko neurri eraginkorrak hartu beharko lirateke, eta neurri horiek maila sozial guztietara iristen direla egiaztatu, maila sozial baxuetan arazo hau larriagoa baita.

Gako-hitzak: umea, gehiegizko pisua, obesitatea, gainpisua, gorputz-masaren indizea

\section{Abstract}

The aim of this study was to investigate the weight trends of the children in Gipuzkoa from birth to 7 years of age, taking into consideration the influence of parental anthropometric and sociodemographic characteristics. The subjects of this study were 450 mother-child pairs of the INMA Gipuzkoa cohort. Based on Body Mass Index (BMI) measurements at birth, and at 1, 4 and 7 years, excess weight (EW), overweight and obesity, was defined as $\geq 90$ percentile at birth, and $\geq 85$ percentile at remaining ages. The anthropometric variables of children and parents, type of breastfeeding, food questionnaire at age 4, parental smoking habits during pregnancy and 
socioeconomic variables were analysed. A logistic regression model was used. At birth $11 \%$ of children had EW, $49 \%$ at age 1, 36\% at age 4 and $38 \%$ at age 7 . Heavy birth-weight and rapid growth during the first year were associated with EW in subsequent years. Girls at ages 4 and 7 showed a greater risk of EW than boys. Breastfeeding was not significantly associated with EW. EW increased with the satieted consumption of proteins and carbohydrates at age 4 and of carbohydrates and saturated fats at age 7. Parity increased the risk of EW at birth. Parental BMI was associated with children's EW at all ages. The low educational level of the father and the non-native origin of the mother were associated with EW at birth and at age 4, respectively. The risk of EW increased among father smokers, but not among mother smokers. The prevalence of EW is very high in children. Effective measures should be taken to address this important health problem.

Key words: children, excess weight, obesity, overweight, body mass index.

Bidalia: 2018-09-11

Onartua: 2018-11-17

http://doi.org/10.26876/osagaiz.2.2018.185

\section{Sarrera eta helburuak}

Obesitatearen prebalentzia ia hirukoiztu egin da mundu osoan azken lau hamarkadetan. 2016an 0-5 urteko 41 milioi umek eta 5-19 urteko 340 milioi umek gainpisua edo obesitatea zuten $(1,2)$. Kopuru horiek ikusita, gaur egun obesitatea mundu mailako pandemia kontsideratzen da, urtero batez beste 2,8 milioi pertsona hiltzen direlarik gehiegizko gantz-metaketak sortutako gaixotasun horren konplikazioen ondorioz $(1,3)$.

Haurtzaroko gainpisuak osasunean ondorio larriak dakartza bizitza guztirako, besteak beste gaixotasun kronikoen hasiera goiztiarra (diabetes mellitusa, gaixotasun kardiobaskularrak...), arazo psikosozialak eta ikasketetan errendimendu baxuagoa (3). Gainera, pisua galtzea zein galera hori mantentzea zaila denez, helduaroko obesitatea ere errazten du, epe luzera horrek dituen komorbilitate larriekin: gaixotasun kardiobaskularrak, diabetes mellitusa, minbiziak (endometrioa, bularra, obulutegia, prostata, gibela, giltzurruna edo kolona), giltzurrun-gaixotasun kronikoa, asaldura muskulu-eskeletikoak, bai eta horien ondoriozko heriotza ere (3).

Klasikoki, herrialde garatuetako helduen arazotzat hartu izan da, baina azken hamarkadetan gainpisua eta obesitatea umeetan eta garatze bidean diren herrialdeetan (errenta baxu edo ertaina dutenetan) bereziki hedatu da $(1,3)$. Metaanalisi baten arabera, 2000tik egun arte gorputz-masaren indizearen (GMI) igotzeko joerak goi-lautada itxura hartu du herrialde garatuetan, pandemiaren hedapena geldituz (2). Herrialde azpigaratuetan, ordea, pisu-eskasiatik gainpisurako trantsizioa oso azkarra izateaz gain, GMlak gora egiten jarraitzen du. Mundu mailan oraindik pisu-eskasia obesitatea baino prebalenteagoa da, baina orain arteko joerak jarraitzen badu, 2022rako obesitatea gainjartzea espero da (2).

Datu hauek adierazten dute baldintza sozial eta ekonomikoek osasunean eragina daukatela, umearengan eta amarengan, batik bat. Osasuneko Eragile Sozialen Batzordeak (Commission on Social Determinants of Health) azaltzen du mekanismo sozial, ekonomiko eta politikoek maila sozioekonomiko jakin batzuk sorrarazten dituztela. Horien bitartez gizartea mailakatzen da haien diru-sarrera, hezkuntza, lanpostu, genero, etnia eta beste faktore batzuen arabera. Aldi berean, eragile horiek osasun-egoera baldintzatzen dute, gizarte-hierarkian dauden lekuaren arabera banakoek esposizio eta ahultasun desberdinak dituztelako (4). Gaur egungo obesitatearen banaketa soziala ez da lehengo berdina, baina oraindik desberdintasun nabariak daude maila sozioekonomiko desberdina dutenen artean. Errenta baxuko herrialdeetan adin ertaineko helduak (emakumeak batik bat) kalterik handiena jasaten dutenak. Errenta altuagoko herrialdeetan, aldiz, adin guztietan 
obesitateak antzera eragiten die bi sexuei, baina maila sozioekonomiko baxukoen artean obesitatearen prebalentzia altuagoa da (5).

Lan honen helburua Gipuzkoako umeen pisuaren eboluzioa eta gehiegizko pisurako (GP) joera aztertzea da, jaiotzetik 7 urtera bitarte, herrialde garatu batean, hain zuzen, gurasoen ezaugarri soziodemografiko eta biologikoek bilakaera horretan duten eragina ikertuz.

\section{Material eta metodoak}

\subsection{Populazioa eta lagina}

INMA -INfancia y Medio Ambiente- (Haurtzaroa eta Ingurumena) proiektua Espainiako 7 lekutako ama-ume kohorte-ikerketa multizentriko prospektiboa da. Haurren hazkundea eta garapena aztertzen ditu ingurumen-baldintzei lotuta. Proiektu horren xehetasun metodologikoak aurretik publikatuak izan dira (6). Haurdun zeuden emakumeak 2006ko maiatza eta 2008ko urtarrila artean sartu ziren proiektu honetan, haurdunaldiko lehen hiruhilekoko (12.-15. asteak) kontsultan, euren erreferentziazko zentroetan. Ondoren, 3. hiruhilekoan; haurra jaiotzean; 1., 4. eta 7. urteetan jarraipena egin zitzaien, galdeketak, miaketa fisikoak edo bestelako proga osagarriak eginez aldiro. Sartze-irizpideak hauek izan ziren: amek 16 urte baino gehiago izatea, haurdunaldi bakarra izatea, erreferentziazko zentroan erditzeko asmoa izatea, komunikazio-arazorik ez izatea eta erreprodukzio naturala; guztira 2.616 ama-ume bikote elkartuz. Horien artean abortu (naturala edo eragindakoa) edo fetu-heriotza jasandakoak ikerketatik kanpo geratu ziren. Lan honetan Gipuzkoako azpikohortea erabili da: 638 ama-ume diada (bikote), Zumarragako ospitale publikoan 2006 eta 2007an jaiotako haurrek eta euren amek parte hartu dute. Lehenengo segimendua ospitalean bertan burutu zen, hurrengoak, berriz, Goierriko eta Urola Kostako zenbait udalekin elkarlanean aurrera eraman ziren. Horietatik 1., 4. eta 7. urteetako pisuari eta altuerari buruzko datuak ez zeuzkaten bikoteak ikerketatik kanpo geratu dira, 450 ama-ume bikoteko lagina lortuz.

Ikerketa honetarako partaideek baimen informatua bete zuten, adostasuna adieraziz, eta Donostia Unibertsitate Ospitaleko Etika Batzordeak onartu zituen ikerketaren baldintzak.

\subsection{Umeen ezaugarri antropometrikoak eta hazkundea}

Jaioberrien pisua $(\mathrm{g})$ erditzean parte hartutako emaginek neurtu zuten eta luzera $(\mathrm{cm})$ ospitaleko erizainek lehen 12 orduetan. 1., 4. eta 7. urteetako neurketa antropometrikoak, aldiz, protokolo estandarizatuen erabileran trebatutako langileek egin zituzten. Oinarrizko ezaugarri antropometriko horietatik abiatuta kalkulatu ziren umeen altuerarako pisua (weight-for-height), GMla, adinerako GMla (BMI-for-age) eta lan honetan erabili ez diren bestelako datu batzuk. Horiek Z-score bihurtu ziren erreferentziazko populazioarekin konparatzeko. Z-score sistemak adierazten du balio zehatz bat erreferentziazko batezbesteko edo medianatik zenbat desbiderapen tipikoz (DT) aldentzen den, -2DT eta +2DT arteko balioak normaltzat hartuz (7).

Halaber, hazkunde-abiadura kalkulatu genuen jaiotza eta 12 hilabeteren artean. Pisu-hazkunde azkarra kontsideratzen da pisuaren Z-score hazkunde > 0,67 DT denean.

\subsection{Umeen gehiegizko pisua (GP)}

GP kontzeptua erabili da gomendatutako pisua baino altuagoa definitzeko. Kontzeptu honek barne hartzen ditu jaiotzean haurdunaldi-adinerako handia izatea eta gainerako adinetan ( 1,4 eta 7$)$ gainpisua zein obesitatea izatea. Gainpisu eta obesitate terminoek gehiegizko gantz-metaketari egiten diote erreferentzia. Bestalde, ikerketari indar estatistikoa emateko, kontuan hartuta laginaren neurriaren muga eta obesitatearen prebalentzia, gainpisua eta obesitatea elkarrekin aztertu dira.

Eguneroko praktika medikoan ez daude eskura gorputzeko gantz-proportzioa zuzenean neurtzeko gailuak, horregatik, GPa estimatzeko ezaugarri antropometrikoen (pisua eta altuera) erlazioak

$$
\text { Osagaiz - } 2018-2 \text {. bolumena - 2. zk. }-49
$$


Iratxe Escudero Otxandorena, Eva Pereda-Pereda, Izaro Babarro Velez, Juan J. Aurrekoetxea Agirre

neurtzen dira, helburu klinikoetarako behar den zehaztasun nahikoa dutelako. Helduetan 2.6. atalean aipatutako GMla erabiltzen da. Umeetan pisua eta altuera sexuarentzat eta adinarentzat espezifikoak diren erreferentziazko populazioen datuekin konparatu behar dira. Lan honetan Carrascosa eta lagunen taulak erabili dira (8), Espainiako populazioan oinarritutako hazkunde-taula estandarizatuak. Haurdinaldi-adinerako handiak kontsideratzen dira jaiotzako pisua $>$ p90 denean. Gainerako adinetan $(1,4$ eta 7 urte), gainpisua $\geq$ p85 eta $<$ p90 denean, obesitatea $\geq$ p90, eta horrenbestez, GP $\geq$ p85 bezala definitu genuen.

\subsection{Umeen edoskitzea eta elikadura}

Umeen edoskitzearen iraupena lau kategoriatan banatu zen: 0 hilabete, 1-16 hilabete, 17-24 hilabete eta 24 hilabete baino gehiago. Edoskitze mota, aldiz, hiru kategoriatan banatu zen: edoskitze natural esklusiboa (amarengandik), mistoa (naturala eta artifiziala) eta edoskitze artifiziala (amarena $<7$ egun barne).

Umeen elikadura 4. urteko ebaluazioan neurtu zen. Berrikuspen horretan gurasoei umeen elikadurari buruz galdetu zitzaien. Horren ebaluaziorako 101 elementuko janari-maiztasunaren galde-sorta (food frequency questionnaire) erdikuantitatiboa erabili zen. Energia-kontsumoa guztira (kcal/egun), proteinak (g/egun), karbohidratoak (g/egun) eta gantzak (guztira, aseak, monoasegabeak eta poliasegabeak; g/egun) aztertu ziren. Elikagai bakoitza eguneroko energia-kontsumo totalarekin doitu zen.

\subsection{Gurasoen ezaugarri soziodemografikoak}

Amaren adinari, paritateari, gurasoen jatorriari (Espainia edo besteak), ikasketa-mailari eta lanpostuari buruzko informazioa aurrez aurreko elkarrizketetan pasatutako bi galde-sorten bitartez jaso zen.

Egoera sozioekonomikoaren ebaluaziorako ikasketa-maila eta lanpostuaren inguruko datuak erabili ziren. Lehenengoa kalkulatzeko eskolatze-urteak hartu ziren kontuan, hiru taldetan banatuz: lehen hezkuntza ( $\leq 11$ eskolatze-urte), bigarren hezkuntza (12-15 eskolatze-urte) eta goimailako/unibertsitate ikasketak ( $\geq 16$ eskolatze-urte). Lanpostua, aldiz, haurdun geratu aurreko lana kontuan hartuta taldekatu zen, British Registrar General's Social Class delakoaren klase sozialen egokitzapen erdaldunaren ereduari jarraituz (9), bost kategoria bereizi ziren altuenetik baxuenera: I, $\geq 10$ langileko enpresa-zuzendariak, goi-teknikariak eta goi-mailako profesionalak; II, < 10 langileko enpresa-zuzendariak eta erdi-mailako profesionalak; III, finantza-kudeatzaileak, administrariak eta beste laguntza-langileak, autonomoak, eskulangileen ikuskatzaileak eta eskulangileak ez diren langile kualifikatuak; IV, eskulangile kualifikatuak eta erdikualifikatuak; eta V, eskulangile ez kualifikatuak. Lanpostua da klase sozialen estratifikaziorako aldagai erabiliena soziologia, epidemiologia, osasun publiko eta beste zenbait arlotan, askotan klase sozialaren ordezkotzat erabiliz, lan honetan egin zen bezala.

\subsection{Gurasoen bestelako aldagaien informazioa}

Tabako-kontsumoari dagokionez, gurasoen datuak jaso ziren. Amaren kasuan haurdunaldian zehar edukitako tabako-kontsumoa lau kategoriatan banatu zen: inoiz ez du erre, haurdunaldian zehar erre egin du, erretzaile ohia da, eta haurdunaldian zehar utzi du. Aitaren kasuan, aldiz, haurdunaldian erretzailea zen ala ez hartu zen kontuan.

Gurasoen pisuaren egoera aztertzeko GMla erabili genuen, eta hori, helduek esandako pisuaren eta altueraren karratuaren arteko zatiketa $\left(\mathrm{kg} / \mathrm{m}^{2}\right)$ eginez kalkulatu zen. Lau talde banatu genituen: pisu eskasa $(\mathrm{GMI}<18,5)$, pisu egokia $(18,5 \leq \mathrm{GMI}<25)$, gainpisua $(25 \leq \mathrm{GMI}<30)$ eta obesitatea $(\mathrm{GMI} \geq$ 30). Amaren GMla kalkulatzeko haurdun geratu aurreko GMla hartu genuen kontuan (aurre-GMI). 
Haurdunaldian zehar irabazitako pisua kalkulatzeko 39. eta 12. asteetako pisuen arteko kenketa egin genuen, irabazitako pisua gomendatutakoa, gomendatutakoa baino baxuagoa edo gomendatutakoa baina altuagoa zen ikusteko. Amaren aurre-GMlaren arabera, pisu-irabazteko gomendioak desberdinak dira: 12,5-18 kg haurdun dauden pisu baxuko emakumeentzat, 11,5-16 kg pisu egokidunentzat, 7-11,5 kg gainpisua dutenentzat eta 5-9 kg obesitatea dutenentzat (10).

\subsection{Analisi estatistikoak}

Estatistiko deskribatzaileak erabili genituen gurasoen ezaugarri sozioekonomikoak eta umeen ezaugarri antropometrikoak azaltzeko: batezbestekoa eta DTa aldagai jarraituentzat; eta maiztasun absolutuak ( $\mathrm{N}$ ) eta portzentajeak (\%) aldagai kategorikoentzat. Aldagai bakoitzean galdutako datuak adierazi ziren.

Aldagai askeen (gurasoen ezaugarri soziodemografikoak, tabako-kontsumoa eta GMla aldagaiak; umearen sexua, haurdunaldi-adinerako txikia edo handia eta pisu-hazkundea azkarra) eta mendeko aldagaiaren (umeen GParen) arteko erlazioa ikertzeko odds ratioak (OR) kalkulatu genituen haien $\% 95$ eko konfiantza-tarteekin (\% 95KT), erregresio logistikoa erabiliz, arrisku-faktoreen loturaren indarra kalkulatzeko.

Azkenik, erregresio logistiko anizkoitza erabili genuen umeen GPan aldagai nahasleen eragina murrizteko eta aldagai bakoitzaren eragin zuzena (independentea) GPan ikusteko. Ereduetan mendeko aldagaiarekin $p<0,10$ balioarekin lotzen zirenak mantendu ziren, nahasleen eragina murrizteko. Estatistikoki esanguratsutzat $p<0,05$ balioak zituzten emaitzak hartu genituen. Datuen analisi estatistikorako IBM SPSS 17.0 softwarea (IBM Corporation, Armonk, NY, AEB) eta Excel orria erabili genituen.

\section{Emaitzak}

\subsection{Gurasoen ezaugarri soziodemografikoak, tabako-kontsumoa eta GMla}

Ikerketa honetako 450 familietako gurasoen ezaugarri soziodemografikoak 1. taulan azaltzen dira. Amen batez besteko adina 31,4 urtetakoa zen, ia guztiak $(\% 97,1)$ espainiar jatorrikoak zirelarik; aiten antzera (\% 98,2). Gehienentzat honakoa lehen haurdunaldia (\% 55,6) edo bigarrena (\% 38,9) zen.

Lanpostuaren araberako klase sozialaren sailkapenean, desberdintasunak aurkitu genituen ama eta aiten artean. Oro har, amak maila sozial altuagokoak ziren aitak baino. Amen gehiengoa III. (\% 29,1) eta IV. (\% 31,1) maila sozioekonomikoan kokatuta zeuden, eta, aldiz, aiten erdia baino gehiago $(\% 53,7)$ IV. mailan kokatzen ziren,III. klase sozialean \% 29,1 soilik kokatzen zirelarik.

Ikasketa-mailek ezberdintasun handia zuten: amen \% 53,1ek unibertsitate-ikasketak eta \% 36,2k bigarren hezkuntzakoak zituzten. Aiten kasuan, aldiz, ia erdiek (\% 49,4) bigarren hezkuntzako ikasketak zituzten eta soilik \% 29,1ek unibertsitate-ikasketak .

Amen $\% 50,2 \mathrm{k}$ ez zuen inoiz tabakorik kontsumitu eta \% 27,4 erretzaile ohia zen. Gainerakoak ikerketa unean kontsumitzaileak ziren: \% 12,3k haurdunaldian utzi zion erretzeari eta \% 10,1ek erretzen jarraitu zuen haurdun egon arren. Aiten \% 26,3 erretzailea zen eta \% $11,6 \mathrm{k}$ etxean erretzen zuen haurdunaldian zehar (1. taula).

Ama gehienen (\% 76,9) haurdun geratu aurreko GMla egokia zen, baina $\% 14,7 \mathrm{k}$ gainpisua eta $\% 4,4 \mathrm{k}$ obesitatea zuten. Ostera, aiten erdiek gainpisua $(\% 43,1)$ edo obesitatea $(\% 7,3)$ zeukaten.

\subsection{Umeen ezaugarri antropometrikoak, hazkundea eta edoskitzea}


Iratxe Escudero Otxandorena, Eva Pereda-Pereda, Izaro Babarro Velez, Juan J. Aurrekoetxea Agirre

Umeen ezaugarri antropometrikoak 2. taulan deskribatzen dira. Erdiak neskak ziren (\% 51,6). Ikerketan zehar umeen pisuaren batez bestekoaren eboluzioa honakoa izan zen: $3,3 \mathrm{~kg}$, 1 . urtean $10,4 \mathrm{~kg}$, 4. urtean $18,6 \mathrm{~kg}$ eta 7 . urtean $28,6 \mathrm{~kg}$-koa.

GPari dagokionez, jaio ziren umeetatik \% 10,9 haurdunaldi-adinerako handiak ziren; 1 . urtean \% 49,2k gainpisua edo obesitatea zuen; 4. urtean, \% 35,5ek; eta 7. urtean, \% 37,9k. Joera hori 1. irudian azaltzen da. Umeen \% 38,7k bizitzako lehen 12 hilabeteetan pisu-hazkunde azkarra izan zuen.

Gehien nagusitu zen edoskitze mota mistoa (\% 61,3) izan zen. Umeen \% 27,3k edoskitze esklusiboki naturala jaso zuen eta \% 11,4k edoskitze artifiziala (esklusiboki edo naturala $<7$ egun). Edoskitzearen iraupenari dagokionez, ama gehienek 1-16 hilabetez $(\% 35,6)$ edo $17-24$ hilabetez $(\% 36,2)$ eman zieten bularra beren seme-alabei.

\subsection{Guraso eta umeen ezaugarriak umearen GParekin erlazionatuta}

Aldagai biko analisian (3. taula) gurasoen eta umeen GPen arteko lotura azaltzen da. Amaren paritateak jaiotzako GParekin lotura positibo eta estatistikoki esanguratsua azaldu zuen eta amaren adina esanguraren mugan zegoen. Aitaren jatorriak 4. urteko GParekin lotura esanguratsua azaldu zuen eta 1. urtean esanguraren mugan zegoen. Gurasoen jatorriaren eta jaiotzako GParen arteko lotura ezin izan genuen neurtu, ez zegoelako haurdunaldi-adinerako ume handirik Espainia ez den beste herrialdeetatik etorritako familietan.

Klase sozioekonomikoari dagokionez, amaren kasuan 7. urteko GParekin lotura esanguratsua agertu zen, ez, ordea, aiten kasuan. Bestalde, amaren unibertsitate-ikasketek esanguraren aldetik babesfaktoretzat jokatzen zuten 7. urtean.

Tabako-kontsumoaren eraginak esangura estatistikoa azaldu zuen, haurdunaldian erretzeari utzi zioten amen eta haurren 4. eta 7. urteetako GParen artean, arriskua areagotuz; eta aitaren kasuan, erretzaileen eta 4. urteko GParen artean. Gurasoen GMlak arrisku-faktoretzat jokatu zuen umearen GPan urte guztietan. Izan ere, amaren gainpisu eta obesitateak 4. urtetik eta aitarenak jaiotzatik 7. urtera bitarte lotura esanguratsu eta positiboa erakutsi zuten.

Amek haurdunaldian zehar irabazitako pisuak ez zuen lotura esanguratsurik izan aldagai biko analisian. Umeen ezaugarriei dagokienez, umearen edoskitze-iraupenak, edoskitze motak zein elikadurak ere ez zuten lotura esanguratsurik erakutsi.

Haurdunaldi-adinerako handiak ziren umeek 1. urtean GPa izateko arrisku esanguraz altuagoa zuten. Jaiotzaren eta lehenengo urtearen artean pisu-hazkunde azkarra izan zuten umeengan 1-7 urte bitartean GPrako arrisku esanguratsua azaldu zen: 1 . urtean $\mathrm{OR}=4,38(2,79-6,89) ; 4$. urtean $\mathrm{OR}=2,62$ $(1,67-4,10)$; eta 7 . urtean $\mathrm{OR}=2,28(1,44-3,61)$.

Erregresio logistiko anizkoitzaren emaitzak 4. taulan azaltzen dira. Gurasoei dagokienez, paritatea jaiotzako pisuarekin lotzen zen, soilik. Gurasoen GMlek erlazio konstantea erakutsi zuten: amaren aurre-GMlak 1. eta 7. urteetan; eta aitarenak jaiotzean eta 4 eta 7 urtetara.

Aldagai sozialek ere lotura esanguratsua mantentzen zuten neurri batean: aiten ikasketa baxuak jaiotzako GParekin eta ama atzerritarra izateak 4. urteko GParekin. Aita erretzaileen umeek GPa edukitzeko arrisku handiagoa zuten 4. urtean, eta 7. urtean esangura estatistikotik gertu.

Umeen aldagaiei dagokienez, neskek GPa edukitzeko arrisku handiagoa zuten 4. urtean. Jaiotzean haurdunaldi-adierako handiak ziren umeek 1. eta 4. urtean GP hori mantentzen zuten, eta 7. urtean ere, esanguraren mugan. Halaber, lehen urtean pisu-hazkunde azkarra izan zutenek ere mantentzen zuten GPa 4. eta 7. urteetan.

Elikagaiei dagokienez, doitutako erregresio logistiko anizkoitzean karbohidratoek eta gantz aseek zein poliasegabeek 7. urtean lotura estatistiko esanguratsu eta positiboa azaldu zuten. Eta 4. urtean 
gantzak, oro har, esanguraren mugan erlazionatzen ziren GParekin. Karbohidratoek eta proteinek, berriz, esanguraz areagotzen zuten GPa. Edoskitzea, bestalde, ez zen lotzen GParekin.

\section{1. taula. Gurasoen ezaugarri soziodemografikoak, bizimodua eta elikadura}

\begin{tabular}{|c|c|c|c|c|}
\hline & & $\mathrm{N}$ & $\%$ & Galdu \\
\hline $\begin{array}{l}\text { Aldagai soziodemografikoak: } \\
\text { Amaren adina }\end{array}$ & Batezbestekoa \pm DTa & 45 & $31,4 \pm 3,4$ & 0 \\
\hline \multirow[t]{3}{*}{ Paritatea } & 0 & 25 & 55,6 & 0 \\
\hline & 1 & 17 & 38,9 & \\
\hline & $\geq 2$ & 25 & 5,6 & \\
\hline \multirow[t]{2}{*}{ Amaren iatorria } & Espainia & 43 & 97,1 & 0 \\
\hline & Besteak & 13 & 2,9 & \\
\hline \multirow[t]{2}{*}{ Aitaren iatorria } & Espainia & 44 & 98,2 & 0 \\
\hline & Besteak & 8 & 1,8 & \\
\hline \multirow[t]{5}{*}{ Amaren klase soziala $^{a}$} & 1 & 78 & 17,3 & 0 \\
\hline & II & 71 & 15,8 & \\
\hline & III & 13 & 29,1 & \\
\hline & IV & 14 & 31,1 & \\
\hline & V & 30 & 6.7 & \\
\hline \multirow[t]{5}{*}{ Aitaren klase soziala ${ }^{a}$} & 1 & 49 & 11,1 & 7 \\
\hline & II & 75 & 16,9 & \\
\hline & III & 61 & 13,8 & \\
\hline & IV & 23 & 53,7 & \\
\hline & $\mathrm{V}$ & 20 & 4,5 & \\
\hline \multirow[t]{3}{*}{ Amaren ikasketa-maila } & Lehen hezkuntza & 48 & 10,7 & 2 \\
\hline & Bigarren hezkuntza & 16 & 36,2 & \\
\hline & Unibertsitarioak & 23 & 53,1 & \\
\hline \multirow[t]{3}{*}{ Aitaren ikasketa-maila } & Lehen hezkuntza & 96 & 21,5 & 3 \\
\hline & Bigarren hezkuntza & 22 & 49,4 & \\
\hline & Unibertsitarioak & 13 & 29,1 & \\
\hline \multicolumn{5}{|l|}{ Tabako-kontsumoa eta GMla: } \\
\hline \multirow[t]{4}{*}{ Amaren tabako-kontsumoa } & Inoiz ez du erre & 22 & 50,2 & 12 \\
\hline & Haurdunaldian zehar & 44 & 10,1 & \\
\hline & Erretzaile ohia & 12 & 27,4 & \\
\hline & Haurdunaldian zehar & 54 & 12,3 & \\
\hline \multirow[t]{2}{*}{ Aitaren tabako-kontsumoa } & Ez erretzailea & 32 & 73.7 & 12 \\
\hline & Erretzailea & 11 & 26,3 & \\
\hline \multirow[t]{4}{*}{ Amaren aurre-GMla ${ }^{b}$} & Pisu baxua & 18 & 4,0 & \\
\hline & Egokia & 34 & 76,9 & \\
\hline & Gainpisua & 66 & 14,7 & \\
\hline & Obesitatea & 20 & 4,4 & \\
\hline \multirow[t]{3}{*}{ Haurdunaldian irabazitako } & Gomendatutakoa & 17 & 42,1 & 34 \\
\hline & > gomendatutakoa & 97 & 23,3 & \\
\hline & < gomendatutakoa & 14 & 34,6 & \\
\hline \multirow[t]{4}{*}{ Aitaren GMIab } & Pisu baxua & 1 & 0,2 & 11 \\
\hline & Egokia & 21 & 49,4 & \\
\hline & Gainpisua & 18 & 43,1 & \\
\hline & Obesitatea & 32 & 7,3 & \\
\hline
\end{tabular}

Laburdurak: DT: desbiderapen tipikoa; GMI: gorputz-masaren indizea; aurre-GMI: haurdun geratu aurreko GMla.

a: Lanpostuen mailan oinarritutako klase sozialaren sailkapena.

b: Osasunaren Mundu Erakundearen (OME) sailkapenean oinarrituta. 
1. irudia. Umeen gehiegizko pisuaren eboluzioa jaiotzetik 7. urtera (\%)

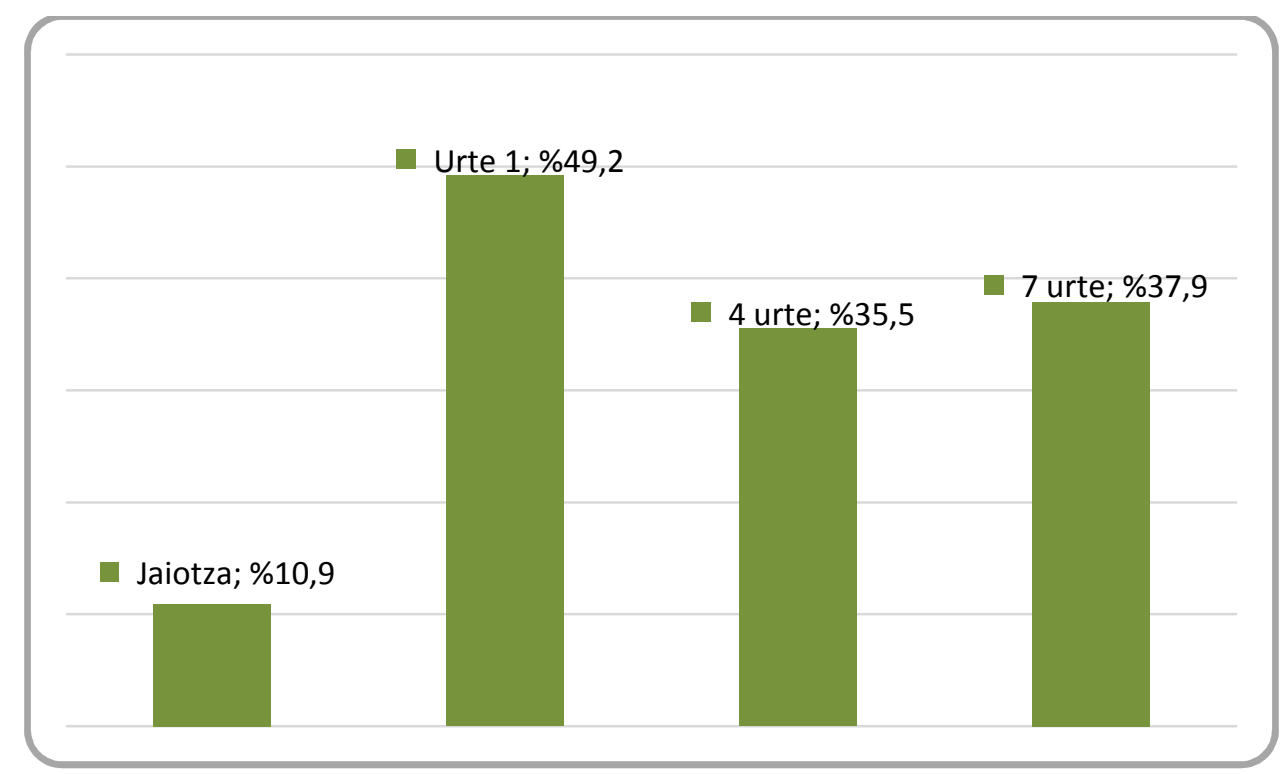


2. taula. Umeen ezaugarri antropometrikoak; jaiotzean, urtebetera, 4 urtetara eta 7 urtetara

\begin{tabular}{|c|c|c|c|c|c|c|c|c|c|c|c|c|c|}
\hline & \multicolumn{3}{|c|}{ Jaioberria } & \multicolumn{3}{|c|}{1 urte } & \multicolumn{3}{|c|}{4 urte } & \multicolumn{3}{|c|}{7 urte } \\
\hline & & $\mathrm{N}$ & $\%(X \pm$ & Galdua & $\mathrm{N}$ & $\%(X \pm$ & Galdua & $\mathrm{N}$ & $\%(X \pm D T)$ & Galdua & $\mathrm{N}$ & $\%(X \pm$ & Galduak \\
\hline \multirow[t]{2}{*}{ Sexua } & Neska & 232 & 51,6 & 0 & 232 & 51,6 & 0 & 232 & 51,6 & 0 & 23 & 51,6 & 0 \\
\hline & Mutila & 218 & 48,4 & & 218 & 48,4 & & 218 & 48,4 & & 21 & 48,4 & \\
\hline Pisua (kg) & Batezbestekoa & 446 & $3,3 \pm 0,5$ & 4 & 382 & $10,4 \pm$ & 68 & 412 & $18,6 \pm 2,5$ & 38 & 39 & $28,6 \pm$ & 59 \\
\hline Altuera $(\mathrm{cm})$ & Batezbestekoa & 420 & $48,9 \pm$ & 30 & 378 & $76,4 \pm$ & 72 & 412 & $106,4 \pm$ & 38 & 39 & 127,9 & 59 \\
\hline \multirow[t]{2}{*}{ Haurdunaldi- } & Ez & 394 & 89,2 & 8 & & & & & & & & & \\
\hline & Bai & 48 & $10,9^{a}$ & & & & & & & & & & \\
\hline \multirow[t]{2}{*}{ Pisu-hazkuntza azkarra } & Ez & & & & 230 & 61,3 & 75 & 230 & 61,3 & 75 & 23 & 61,3 & 75 \\
\hline & Bai & & & & 145 & 38,7 & & 145 & 38,7 & & 14 & 38,7 & \\
\hline \multirow[t]{2}{*}{ Gainpisua/obesitatea } & Ez & & & & 187 & 50,8 & 82 & 265 & 64,5 & 39 & 24 & 62,1 & 59 \\
\hline & Bai & & & & 181 & $49,2^{\mathrm{a}}$ & & 146 & $35,5^{a}$ & & 14 & $37,8^{a}$ & \\
\hline \multirow[t]{4}{*}{ Edoskitze-iraupena } & 0 & 77 & 14,8 & 116 & & & & & & & & & \\
\hline & $1-16$ & 186 & 35,6 & & & & & & & & & & \\
\hline & $17-24$ & 189 & 36,2 & & & & & & & & & & \\
\hline & $>24$ & 70 & 13,4 & & & & & & & & & & \\
\hline \multirow[t]{3}{*}{ Edoskitze mota } & Naturala & 148 & 27,3 & 96 & & & & & & & & & \\
\hline & Mistoa & 332 & 61,3 & & & & & & & & & & \\
\hline & Artifiziala & 62 & 11,4 & & & & & & & & & & \\
\hline \multirow{7}{*}{$\begin{array}{l}\text { Energia-sarrera totala } \\
\text { Proteinak }^{\mathrm{b}} \\
\text { Karbohidratoak }^{\mathrm{b}} \\
\text { Gantzak }^{\mathrm{b}}\end{array}$} & & & & & & & & 343 & $298,7 \pm$ & 107 & & & \\
\hline & & & & & & & & 403 & $64,9 \pm 5,5$ & 47 & & & \\
\hline & & & & & & & & 403 & $181,5 \pm$ & 47 & & & \\
\hline & Guztira & & & & & & & 403 & $52,2 \pm 5,7$ & 47 & & & \\
\hline & Aseak & & & & & & & 403 & $20,3 \pm 3,2$ & 47 & & & \\
\hline & Monoasegabea & & & & & & & 403 & $19,6 \pm 3,2$ & 47 & & & \\
\hline & Poliasegabeak & & & & & & & 403 & $7,9 \pm 1,6$ & 47 & & & \\
\hline
\end{tabular}

Laburdurak: X: batezbestekoa; DT: desbiderapen tipikoa; GMI: gorputz-masaren indizea. Zuriz dauden hutsuneetako informazioa ez zen erabili ikerketan.

a: Beste herrialdeetako jatorrizko gurasoen artean jaiotzean ez dago gehiegizko pisuko: Umeen elikadura 4. urteko segimenduan neurtu zen. 
Iratxe Escudero Otxandorena, Eva Pereda-Pereda, Izaro Babarro Velez, Juan J. Aurrekoetxea Agirre

3. taula. Gurasoen ezaugarri soziodemografikoak, tabako-kontsumoa, gurasoen GMla, umearen sexua, haurdunaldi-adinerako handia eta pisu-hazkunde azkarra; umearen gehiegizko pisuarekin lotuta

\begin{tabular}{|c|c|c|c|c|c|}
\hline & \multicolumn{4}{|c|}{ Umearen pisu sobera } \\
\hline & & Jaiotza & 1 urte & 4 urte & 7 urte \\
\hline & & OR (\% 95KT) & OR (\% $95 \mathrm{KT})$ & OR (\% $95 \mathrm{KT})$ & OR (\% $95 \mathrm{KT})$ \\
\hline \multicolumn{6}{|l|}{ Gurasoak } \\
\hline Amaren adina & & $1,09(1,00-1,19)$ & $1,01(0,95-$ & $1,02(0,96-$ & $1,00(0,94-1,06)$ \\
\hline \multirow{3}{*}{ Paritatea } & 0 & 1 & 1 & 1 & 1 \\
\hline & 1 & $3,31(1,69-6,47)$ & $0,78(0,50$ & $0,93(0,61-$ & $1,17(0,76-1,80)$ \\
\hline & $\geq 2$ & $4,11(1,34$ & $0,48(0,17-$ & $0,67(0,27-$ & $1,55(0,60-4,00)$ \\
\hline \multirow[t]{2}{*}{ Amaren jatorria } & Espainia & - & 1 & 1 & 1 \\
\hline & Besteak & $-{ }^{a}$ & $0,82(0,22-$ & $2,31(0,61-$ & $1,66(0,47-5,85)$ \\
\hline \multirow[t]{2}{*}{ Aitaren jatorria } & Espainia & - & 1 & 1 & 1 \\
\hline & Besteak & $-{ }^{a}$ & $8,46(0,98-$ & $9,36(1,08-$ & $2,09(0,38-11,56)$ \\
\hline \multirow[t]{5}{*}{ Amaren klase soziala } & 1 & 1 & 1 & 1 & 1 \\
\hline & II & $2,07(0,66-6,50)$ & $0,82(0,39-$ & $1,45(0,71-$ & $3,79(1,73-8,28)$ \\
\hline & III & $1,98(0,70-5,65)$ & $0,74(0,38$ & $1,43(0,77-$ & $2,57(1,26-5,24)$ \\
\hline & IV & $1,71(0,60-4,90)$ & $0,60(0,31-$ & $1,26(0,68$ & $3,28(1,62-6,63)$ \\
\hline & $\mathrm{V}$ & $1,56(0,35-6,96)$ & $0,51(0,19$ & $1,16(0,45-$ & $3,45(1,31-9,09)$ \\
\hline \multirow[t]{5}{*}{ Aitaren klase soziala } & 1 & 1 & 1 & 1 & 1 \\
\hline & II & $0,61(0,21-1,74)$ & $0,81(0,36-$ & $0,68(0,31-$ & $0,77(0,34-1,72)$ \\
\hline & III & $0,57(0,18-1,76)$ & $0,63(0,26-$ & $0,78(0,34-$ & $0,77(0,33-1,81)$ \\
\hline & IV & $0,57(0,24-1,36)$ & $0,57(0,28$ & $0,68(0,35-$ & $0,98(0,49-1,96)$ \\
\hline & $\mathrm{V}$ & $0,56(0,11-2,88)$ & $0,30(0,09$ & $1,07(0,35-$ & $0,95(0,31-2,98)$ \\
\hline \multirow[t]{3}{*}{ Amaren ikasketa-maila } & Lehen hezkuntza & 1 & 1 & 1 & 1 \\
\hline & Bigarren hezkuntza & $1,29(0,46-3,62)$ & $1,56(0,75-$ & $1,23(0,62-$ & $0,67(0,33-1,35)$ \\
\hline & Unibertsitarioak & $0,82(0,29-2,31)$ & $1,55(0,76-$ & $0,99(0,51-$ & $0,42(0,21-0,84)$ \\
\hline \multirow[t]{3}{*}{ Aitaren ikasketa-maila } & Lehen hezkuntza & 1 & 1 & 1 & 1 \\
\hline & Bigarren hezkuntza & $0,36(0,17-0,75)$ & $0,91(0,54-$ & $0,66(0,39$ & $0,84(0,50-1,43)$ \\
\hline & Unibertsitarioak & $0,56(0,26-1,21)$ & $1,25(0,69$ & $0,81(0,46$ & $0,83(0,47-1,48)$ \\
\hline \multirow[t]{4}{*}{ Amaren tabako-kontsumoa } & Inoiz ez du erre & 1 & 1 & 1 & 1 \\
\hline & Haurdunaldian erre & $0,51(0,15-1,76)$ & $1,40(0,68$ & $1,19(0,59$ & $1,60(0,81-3,15)$ \\
\hline & Erretzaile ohia & $0,70(0,34-1,47)$ & $0,65(0,40$ & $1,13(0,69$ & $1,09(0,66-1,79)$ \\
\hline & Haurdunaldian utzi & $0,74(0,27-2,03)$ & $1,00(0,52-$ & $1,90(1,01-$ & $2,04(1,03-4,02)$ \\
\hline \multirow[t]{2}{*}{ Aitaren tabako-kontsumoa } & Ez erretzailea & 1 & 1 & 1 & 1 \\
\hline & Erretzailea & $0,67(0,31-1,43)$ & $0,78(0,48$ & $1,59(1,01-$ & $1,27(0,79-2,03)$ \\
\hline \multirow[t]{4}{*}{ Amaren aurre-GMla } & Pisu baxua & 1 & 1 & 1 & 1 \\
\hline & Egokia & $1,95(0,25-$ & $1,58(0,52-$ & $2,44(0,69$ & $2,47(0,69-8,78)$ \\
\hline & Gainpisua & $1,93(0,22-$ & $3,60(1,06-$ & $5,17(1,36-$ & $4,67(1,22-17,87)$ \\
\hline & Obesitatea & $2,82(0,27-$ & $1,20(0,27-$ & $5,00(1,07-$ & $11,20(2,20-$ \\
\hline Haurdunaldian irabazitako & Gomendatutakoa & 1 & 1 & 1 & 1 \\
\hline
\end{tabular}

Osagaiz - $2018-2$. bolumena - 2. zk. -56 


\begin{tabular}{|c|c|c|c|c|c|}
\hline Aitaren GMla & $\begin{array}{l}\text { > gomendatutakoa } \\
\text { < gomendatutakoa } \\
\text { Egokia } \\
\text { Gainpisua } \\
\text { Obesitatea }\end{array}$ & $\begin{array}{c}0,66(0,33-1,32) \\
0,62(0,27-1,44) \\
1 \\
1,73(0,88-3,38) \\
4,28(1,65-\end{array}$ & $\begin{array}{c}1,04(0,60- \\
1,18(0,72- \\
1 \\
1,23(0,80- \\
2,71(1,12-\end{array}$ & $\begin{array}{c}0,64(0,36- \\
1,41(0,87- \\
1 \\
2,29(1,47- \\
6,57(2,89-\end{array}$ & $\begin{array}{c}0,77(0,44-1,35) \\
1,18(0,73-1,90) \\
1 \\
2,33(1,49-3,63) \\
3,00(1,37-6,59)\end{array}$ \\
\hline \multicolumn{6}{|l|}{ Umea } \\
\hline \multirow[t]{2}{*}{ Sexua } & Neska & 1 & 1 & 1 & 1 \\
\hline & Mutila & $1,41(0,77-2,58)$ & $0,75(0,50-$ & $0,82(0,54-$ & $0,90(0,60-1,35)$ \\
\hline Haurdunaldi-adinerako & & & $\begin{array}{c}1 \\
206(104\end{array}$ & $\begin{array}{c}1 \\
1.53 \stackrel{1}{10} 81 .\end{array}$ & $\frac{1}{1,04}(0,54-2,03)$ \\
\hline \multirow[t]{2}{*}{ Pisu-hazkunde azkarra } & $\mathrm{Ez}$ & & 1 & 1 & $\begin{array}{c}1,0+10,0401 \\
1\end{array}$ \\
\hline & Bai & & 4,38 (2,79- & $2,62(1,67-$ & $2,28(1,44-3,61)$ \\
\hline \multirow[t]{3}{*}{ Edoskitze-iraupena } & 0 & & 1 & 1 & 1 \\
\hline & $\begin{array}{l}1-16 \\
17-24\end{array}$ & & $\begin{array}{l}0,83(0,42- \\
0,75(0,38-\end{array}$ & $\begin{array}{l}1,56(0,78- \\
1,39(0,69-\end{array}$ & $\begin{array}{l}1,21(0,59-2,45) \\
1,03(0,50-2,10)\end{array}$ \\
\hline & $>24$ & & $0,68(0,30-$ & $0,99(0,43-$ & $0,75(0,32-1,76)$ \\
\hline \multirow[t]{3}{*}{ Edoskitze mota } & Naturala & & 1 & 1 & 1 \\
\hline & Mistoa & & $0,96(0,61-$ & $1,21(0,76-$ & $1,12(0,70-1,80)$ \\
\hline & Artifiziala & & $0,94(0,43-$ & $0,80(0,36-$ & $0,96(0,42-2,21)$ \\
\hline \multirow{3}{*}{$\begin{array}{l}\text { Energia-sarrera totala } \\
\text { Proteinak }^{\mathrm{b}} \\
\text { Karbohidratoak }^{\mathrm{b}}\end{array}$} & & & & $1,23(0,81-$ & $1,00(0,98-1,03)$ \\
\hline & & & & $1,03(0,99-$ & $0,99(0,95-1,03)$ \\
\hline & & & & $1,00(0,99-$ & $1,00(0,99-1,02)$ \\
\hline \multirow[t]{4}{*}{ Gantzak $^{\mathrm{b}}$} & Guztira & & & $0,99(0,96-$ & $1,00(0,96-1,04)$ \\
\hline & Monoasegabeak & & & $1,00(0,94-$ & $0,96(0,90-1,03)$ \\
\hline & Aseak & & & $0,98(0,92-$ & $1,04(0,97-1,11)$ \\
\hline & Poliasegabeak & & & $1,00(0,88-$ & $0,95(0,83-1,09)$ \\
\hline
\end{tabular}

Laburdurak: OR: odds ratio; Cl: confidence interval edo konfiantza-tartea; GMI: gorputz-masaren indizea; aurre-GMI: haurdun geratu aurreko GMla. a: Beste herrialdeetako jatorrizko gurasoen artean jaiotzean ez dago gehiegizko pisudun umerik.

b: Umeen elikadura 4. urteko segimenduan neurtu zen. 
Iratxe Escudero Otxandorena, Eva Pereda-Pereda, Izaro Babarro Velez, Juan J. Aurrekoetxea Agirre

4. taula. Gurasoen ezaugarri soziodemografikoak, tabako-kontsumoa, gurasoen GMla, umearen sexua, haurdunaldi-adinerako handia eta pisu-hazkunde azkarra, umearen gehiegizko pisuarekin lotuta eta erregresio logistiko anizkoitzean doituta

\begin{tabular}{|c|c|c|c|c|c|}
\hline & & \multicolumn{4}{|c|}{ Umearen pisu sobera } \\
\hline & & Jaiotza & 1 urte & 4 urte & 7 urte \\
\hline & & OR (\% 95KT) & OR (\% 95KT) & OR (\% 95KT) & OR (\% 95KT) \\
\hline \multicolumn{6}{|l|}{ Gurasoak } \\
\hline Paritatea & 0 & 1 & & & \\
\hline & $\begin{array}{l}1 \\
\geq 2\end{array}$ & $\begin{array}{l}2,89(1,44- \\
4,76(1,50-\end{array}$ & & & \\
\hline Amaren aurre-GMla & $\begin{array}{l}\text { Pisu baxua }(\mathrm{GMI}< \\
\text { Egokia }(18,5 \leq \mathrm{GMI}< \\
\text { Gainpisua }(25 \leq \mathrm{GMI}< \\
\text { Obesitatea }(\mathrm{GMI} \geq 30)\end{array}$ & & $\begin{array}{c}1 \\
2,15(0,64- \\
4,13(1,10- \\
1,17(0,23-\end{array}$ & & $\begin{array}{c}1 \\
2,46(0,55- \\
3,94(0,80- \\
20,56(2,32-\end{array}$ \\
\hline Ama atzerritarra & $\begin{array}{l}\text { Ez } \\
\text { Bai }\end{array}$ & & & $\begin{array}{c}1 \\
7,89 \\
(1,23-\end{array}$ & \\
\hline Aitaren GMla & $\begin{array}{l}\text { Ez gainpisua }(18,5 \leq \\
\text { Gainpisua }(25 \leq \\
\text { Obesitatea }(\mathrm{GMI} \geq 30)\end{array}$ & $\begin{array}{c}1 \\
2,00(0,99- \\
3,48(1,26-\end{array}$ & & $\begin{array}{c}1 \\
2,24(1,32- \\
6,02(2,25-\end{array}$ & $\begin{array}{c}1 \\
1,80(1,03-3,15) \\
2,16(0,81-5,75)\end{array}$ \\
\hline Aitaren ikasketa-maila & $\begin{array}{l}\text { Lehen hezkuntza } \\
\text { Bigarren hezkuntza } \\
\text { Unibertsitarioak }\end{array}$ & $\begin{array}{c}1 \\
0,42(0,19- \\
0,61(0,27-\end{array}$ & & & \\
\hline Aitak erretzen zuen & $\begin{array}{l}\mathrm{Ez} \\
\mathrm{Bai}\end{array}$ & & & $\begin{array}{c}1 \\
1,85 \\
(1,05-\end{array}$ & $\begin{array}{c}1 \\
1,73(0,95-3,16)\end{array}$ \\
\hline Umea & & & & & \\
\hline Sexua & $\begin{array}{l}\text { Neska } \\
\text { Mutila }\end{array}$ & & & $\begin{array}{c}1 \\
0,64(0,39-\end{array}$ & \\
\hline Haurdunaldi-adinerako & $\begin{array}{l}\mathrm{Ez} \\
\mathrm{Bai}\end{array}$ & & $\begin{array}{c}1 \\
4,10^{(1,98}\end{array}$ & $\begin{array}{c}1 \\
2,67(1,19\end{array}$ & $\frac{1}{2,34(0,99-5,54)}$ \\
\hline Umearen pisu-hazkuntza & $\begin{array}{l}\text { Ez } \\
\text { Bai }\end{array}$ & & $\begin{array}{c}1 \\
5,69(3,49\end{array}$ & $\begin{array}{c}1 \\
3,00 \\
(1,76-\end{array}$ & $\begin{array}{c}1 \\
2,34(1,32-4,12)\end{array}$ \\
\hline $\begin{array}{l}\text { Karbohidratoak } \\
\text { Proteinak }\end{array}$ & & & & $\begin{array}{l}1,16(1,01- \\
1,20(1,02-\end{array}$ & $1,04(1,01-1,08)$ \\
\hline Gantzak & $\begin{array}{l}\text { Guztira } \\
\text { Aseak } \\
\text { Poliasegabeak }\end{array}$ & & & $1,35(0,98-$ & $\begin{array}{l}1,27(1,06-1,52) \\
1,34(1,00-1,80)\end{array}$ \\
\hline
\end{tabular}

Laburdurak: OR: odds ratio; $\mathrm{Cl}$ : confidence interval edo konfiantza-tartea; GMI: gorputz-masaren indizea; aurre-GMI: haurdun geratu aurreko GMla. Gurasoen aldagai soziodemografikoak, bizimodua eta elikadura aldagaiekin; umeen sexua, haurdunaldi-adinerakotxikia edo handia eta pisu-hazkunde azkarrarekin doide. 


\section{Eztabaida}

Ikerketa honetan azaldutako emaitzen arabera, 1. urtean umeen \% 49k, 4. urtean \% 36k eta 7. urtean \% 38k GPa zuten. 2016an Espainiako Osasun Ministerioak argitaratutako datuen (umeen \% 41,3) antzekoak dira hauek. Espainiako obesitate-tasak igotzen jarraitzen du, Europako altuenetarikoak izanik gaur egun (11). Horrekin, Gipuzkoako umeen GParen tasa oso altua dela esan daiteke.

Umeen gainpisua maila sozioekonomiko baxuekin erlazionatuta dago (12). Gizarte-maila altuetako gurasoek, hezkuntza-maila altuagoa izanik ere, pisu egokiko seme-alabak izaten dituzte; elikadura osasungarriagoa, ariketa fisiko aktiboagoa, pisu-kontrol hobea eta haurdunaldian zainketa egokiagoa izaten dituztelako ezaugarritzat $(13,14)$. Beraz, ingurumen obesogenikoak maila sozioekonomiko baxuagoa duten familietako umeak askoz gehiago kaltetzen ditu (15). Ikerketa honetan aiten klase sozial baxua jaiotzako GParekin lotzen da, nahasleen doitzearen ondoren.

Paritateak jaiotzako GParekin lotura adierazi du erregresio logistikoan. Ama multiparoen artean haurdunaldi aurreko obesitatea dutenek 1,7 aldiz arrisku handiagoa daukate adin gestazionalerako ume handiak izateko, ama nuliparoekin konparatuta (16).

Bi aldagai horiek, hots, maila sozioekonomikoa eta paritatea, 1. eta 7. urteen bitartean ez dira lan honetan GParekin lotzen, baina adin horietan bi faktore azaltzen dira modu konstantean: adin gestazionalerako handia izatea eta lehenengo urtean hazkunde azkarra izatea. Jaiotzean umearen pisu altuak lotura zuzena dauka gainontzeko urteetan GPa izatearekin $(17,18)$. Moschonis et al.-en arabera, adin gestazionalerako handi jaiotako haurrek 12 hilabetetara 2,19 aldiz arrisku handiagoa dute gainpisua izateko (12).

Pisu-hazkunde azkarrak 1-7 urte-bitartean gainpisurako arriskua azaldu du lan honetan, metaanalisi batean (17) eta berrikuspen sistematiko batean (19) bezala. Hazkunde azkar hori pisu baxuko jaioberrietan ikertua izan da konpentsazio-mekanismo moduan. Jaiotzako pisu baxua haurdunaldiko amaren tabako-kontsumoarekin hain lotuta dagoenez, tabakoa eta hazkunde azkarraren ondoriozko gainpisua erlazionatuta egon daitezke. Bestalde, pisu egokiarekin jaiotako haurrek pisua azkarrago hartzea ingurumen-baldintzen ondorio izan daiteke, bereziki, lehenengo urtean umeak egoki ez elikatzeagatik.

Haurdunaldiko amaren tabako-kontsumoak jaiotzean pisu baxuko umeak izateko arriskua handitzen duela jakina da, baina hori ez da lan honen ikerketaren ardatza izan. Gure ikerketan ez da aurkitu GParekin loturarik zeukanik. Faktore horrek maila sozioekonomikoarekin lotura dauka, maila baxuagoko familiek gehiago erretzen dutelako (13). Maila sozioekonomiko altuak eragin positiboa zuen jaiotzako pisuan ikerketa batean (20), baina amek erretzen zutenean efektu onuragarri hori galdu egiten zen.

Epe luzera, aldiz, tabako-kontsumoak haurtzaroko gainpisua sor dezakeela aipatu izan da. Metaanalisi zabal batek haurdunaldian amen tabako-kontsumoak 3.-5. urteetan gainpisua edukitzeko arrisku erlatiboa 1,47an ezarri zuen. Lan honetan ez dira horrelako emaitzarik errepikatzen (17). Lagin honetan \% 10ek erretzen zuen haurdunaldian eta portzentaje hori, laginaren tamainarekin lotuta, izan daiteke arrazoia.

Aiten tabako-kontsumoa 4. eta 7. urteetan gainpisuaren areagotzearekin lotzen da ikerketa honetan. Ez dirudi horren arrazoia mekanismo biologikoak direnik, amaren kontsumo aktiboak eragin askoz handiagoa izango lukeelako, dosi handiagoagatik. Tabakoaren kontsumoak haurdunaldian, epe luzera, umearen gosearen erregulazio-sistema asaldatzen duela eta jaio ostean hazkunde konpentsatzaile oso azkarra izaten dutela uste izan da; baina litekeena da hori ere gurasoen faktore soziodemografikoekin lotuta egotea, haurdunaldian zehar erretzen duten familiak ikasketa-maila baxuagokoak direlako eta, beraz, ingurumen obesogenikoagoan bizi direlako $(12,14,17)$.

Gurasoen GMI altuak umearen GPrako arriskua areagotzen du. Izan ere, ikerketa honetan, gurasoen GMla adin guztietan GParekin lotzen zen. Ezaugarri antropometrikoen herentzia genetikoan hainbat gene egon daitezke inplikatuta: erregulazio homeostatikoan, gosearen erregulazioan eta energia- 
oreka mantentzean parte hartzen duten geneak $(12,17)$. Hala ere, ingurumen obesogenikoaren eraginak ebidentzia handiagoa dauka familietan GPa elkarrekin banatzearen arrazoi bezala. Hamabi mila bikirekin egindako ikerketa batean mutilengan genetikak eta neskengan ingurumenak eragin handiena dutela azaltzen da (21). Gainera, haurdunaldi aurretik gainpisua duten amek haurdunaldian pisu gehiegi hartzeko arrisku handiagoa daukate. Horrek konplikazio obstetriko gehiago eta adin gestazionalerako ume handiagoak izateko arrisku handiagoak dakartza (18).

Umearen bizitzaren hasierako elikadurarako edoskitze naturala gomendatzen da. Osasunaren Mundu Erakundearen (OME) zein Espainiako Osasun Ministerioaren arabera, GParen prebentziorako A gomendio-maila lortu duen bakarra hori da. Edoskitze motak eta iraupenak ez dute inolako lotura esanguratsurik azaldu lan honetan, nahiz eta edoskitze naturala GParen prebentziorako faktore babesle gisa aurretik zabal ikertutako gaia izan (17). Edoskitze artifizialarekin konparatuta, naturala erabiltzean umeek gosearen autorregulazio-sistema hobea dute,jan ondorengo intsulina-jariaketa motelagoa da; eta elikagai solidoak dietan sartzen direnetik aurrera fruta eta barazkietara hobeto egokitzen dira (12). Azalpen biologikoez gain, kontuan izatekoa da ere gurasoen ezaugarriekin duen lotura. Izan ere, edoskitze naturala urriagoa da maila sozioekonomiko baxuagoetan eta obesitatea duten ametan, horien GPrako efektu kaltegarria gehituz aurrekoari $(22,23)$. Gernikan, Pediatriako Lehen Mailako Arretatik egindako ikerketa batean, umeen pisuaren kontrol egokia eta edoskitze naturalaren sustapen eraginkorra lortu arren, ikerketa honetan bezala, edoskitze naturalak ez zuen GPa prebenitzen (24).

Ikerketa honetan umeen elikadura 4. urtean neurtu zen eta umearen GPan eragin zuzena adierazi zuten 4 urterekin dietako karbohidrato, proteina eta gantz orokorren kopuruak eta 7 urterekin karbohidrato eta gantz ase eta poliasegabeek. Azken urteetan, ume eta nerabeen elikadurak izan duen aldaketa nabarietako bat animalia-jatorriko janarien eta azukredun edarien kontsumoa gehitzea izan da; gantz, azukre, elikagai findu eta, oro har, kaloria ugarikoak direnak (24). Horrekin batera, dieta mediterraneoarekiko atxikidura gero eta baxuagoa denez, barazki eta fruta freskoen kontsumoa jaitsi egin da $(11,25)$. Elikadura-baldintza desegoki horiek, ariketa fisikoaren murrizketarekin batera, GParen arrisku-faktore nagusietakoak dira (24).

Dieta, halaber, lotuta dago gurasoen maila sozioekonomikoarekin $(11,25,26)$; izan ere, klase sozial baxua duten populazioetan elikadura ez-osasungarria ohikoagoa da. Horren arrazoia, alde batetik, gantz, azukre, gatz eta kaloria askoko eta mikroelikagai gutxiko janariak merkeagoak izatea eta eskurago egotea izan daiteke (1). Bestetik, gurasoen ikasketa-maila zenbat eta baxuagoa izan, okerragoa da elikadura osasungarriaren inguruko hezkuntza eta arreta eskasagoa jartzen dute, oro har, seme-alaben elikagaiak gainbegiratzean $(22,24)$.

Analisi anizkoitzean, doitzearen ondoren, faktore soziodemografikoek (klase soziala edo ikasketamaila) neurri batean beren eragin independentea galtzen zuten, baina horren azalpena aldagai biologikoen bitartez egin daiteke: gurasoen GMla, paritatea, aitaren tabako-kontsumoa, jatorria, elikadura mota eta umearen jaiotako gainpisua edo hazkunde azkarra lehen urtean.

GParen prebalentziaren igoera azken urteotan ingurumen obesogenikoaren areagotzearen ondorioa izan da, genetikak obesitatearen pandemiaren denborazko aldaketak ez baititu azaltzen. Lan honen emaitzek hipotesi hori indartzen dute. Ingurumen obesogenikoaren kontzeptuak ariketa fisiko gutxi, gailu elektronikoen erabilera handia eta elikadura ez osasungarria ditu ezaugarritzat. Elikadura ez osasungarriak bai gurasoen bai umeen gantz-metaketa areagotzen du. Gurasoen GMI altuak umeak jaiotzean pisu altuagoa izatera eta pisua azkar irabaztera daramatza; horiek, gainera, independenteki umeen hurrengo urteetako GPan eragiten dutelarik.

Hori kontrolatzea OMEren eta herrialde garatuetako gobernuen osasun-sistemen erronka handienetakoa izan da azken hamarkadetan (1). Aldiz, gainpisu eta obesitatearen adierazleek gora egiten jarraitzeak prebentzio-kanpainen eraginkortasuna zalantzan jartzen dute.

Espainian gainpisua duten umeak zituzten familien \% 60k beren seme-alabek pisu egokia zutela kontsideratzen zuten. Pertzepzio hori okerragoa zen klase sozial baxuenetan, hau da, GP-tasa 
altuenak zituzten familietan $(11,26)$. Lortu ditugun emaitzekin argi geratzen da maila sozioekonomikoen arabera pisu-banaketan eta horren arazoaren pertzepzioan desberdintasunak daudela. Horrenbestez, litekeena da prebentzio-mezuak gaizki iristea klase sozial baxuenetara. Horretan esku-hartzea bereziki garrantzitsua da, arazoa mezuaren transmisioa den do beste bat den ikertzeko, konpontzeko eta kontzientzia egokia sortzeko gizarte osoan.

Lan honen mugetako bat laginaren neurria izan da, emaitza esanguratsuak lortzeko zailtasunak sortzen baititu. Bestalde, erabilitako hazkundeko erreferentzia-taulak eta datuen konparaziorako erabilitako beste ikerketenak ez dira beti berdinak izan. Lan honen beste muga bat ariketa fisikoa ez neurtu izana da, gainpisuaren arrazoien ikerketaren aldagai garrantzitsua ere.

Ikerketa honen puntu indartsuen inguruan, INMA kohorteko kalitate-kontroletan sortutako datuen ugaritasuna eta fidagarritasun altua dira. Gainera, GPa umearen bizitzako lau adin ezberdinetan neurtuta dago, pisuaren eboluzioaren jarraipena eginez.

Gipuzkoako umeen GParen prebalentzia oso altua azaltzen da gure lanean. Kontuan izanda obesitatea ekidin daitekeen gaixotasuna dela, honen prebentzioari eta zaintzari behar duten garrantzia eman behar zaio, ahalegin hori eraginkorra izan daitekeela ikusita (27). Esku-hartze horrek elikadura osasungarriagoa sustatu eta energiaren balantzea aldatu beharko luke, ahorakinen eta kontsumoaren aldetik. Haren eraginkortasuna bermatzeko, mezuak gizartearen maila sozioekonomiko guztietara iristen direla ziurtatu beharko litzateke, arazoa larriagoa baita maila sozioekonomiko baxua duten populazioetan.

\section{Eskerrak eta oharrak}

Lehenik eta behin eskerrak eman nahi dizkiegu ikerketa hau posible egin duten familia eta haurrei. Gainera, lan asistentziala aurrera eraman zuten Zumarragako Ospitaleko eta Osasun Zentroetako langileei ere gure esker onak adierazi nahiko genizkieke. Baita proiektu hau aurrera eramateko euren oniritzia eman duten erakundeei ere: Carlos III Osasun Institutua (FIS-PI06/0867, FIS-PI09/00090 eta FIS-PI13/02187), CIBERESP, Eusko Jaurlaritzako Osasun Saila (2005111093, 2009111069, 2013111089 eta 2015111065) eta Gipuzkoako Aldundia (DFG06/002, DFG08/001 eta DFG15/221). Horrez gain, aipagarria da ikerketa-guneko (Zumarraga, Urretxu, Legazpi, Azkoitia, Azpeitia eta Beasain) udalekin urtero egindako hitzarmenei esker lan hau aurrera eramatea posible izan dela. Ildo beretik, Patxi Xabier Txakartegiri eskertu nahi diogu lan honen inguruan egin duen irakurketa kritikoagatik eta bere ekarpenengatik.

\section{Erreferentzia bibliografikoak}

1. World Health Organization. Obesity and overweight. Fact sheet (2018ko otsailean berrikusita). [Internet]. World Heal Organ; 2018. [Kontsulta: 2018-06-26]. Eskuragarri: http://www.who.int/mediacentre/factsheets/fs311/en/

2. Bentham J; NCD Risk Factor Collaboration (NCD-RisC). Worldwide trends in body-mass index, underweight, overweight, and obesity from 1975 to 2016: a pooled analysis of 2416 population-based measurement studies in 128.9 million children, adolescents, and adults. Lancet. 2017; 390: 2627-2642.

3. GBD 2015 Obesity Collaborators. Health Effects of Overweight and Obesity in 195 Countries over 25 Years. N. Engl. J. Med. 2017; 377: 13-27.

4. Solar O, Irwin A. A conceptual framework for action on the social determinants of health. Social Determinants of Health Discussion Paper 2 (Policy and Practice). World Heal Organ; 2010 Nov. 17. [Kontsulta: 2018-06-26]. Eskuragarri: http://www.who.int/sdhconference/resources/ConceptualframeworkforactiononSDH eng.pdf 
5. Swinburn BA, Sacks G, Hall KD, McPherson K, Finegood DT, Moodie ML, Gortmaker SL. The global obesity pandemic: shaped by global drivers and local environments. Lancet. 2011; 378: 804-814.

6. Guxens M, Ballester F, Espada M, Fernández MF, Grimalt JO, Ibarluzea J, Olea N, Rebagliato M, Tardón A, Torrent M, Vioque J, Vrijheid M, Sunyer J. Cohort Profile: The INMA - INfancia y Medio Ambiente- (Environment and Childhood) Project. International Journal of Epidemiology. 2011; 41: 930-940.

7. Philips SM, Shulman RJ. Measurement of growth in children. In: UpToDate, Post TW (Ed) UpToDate. Waltham, MA, 2018 Mar.

8. Carrascosa Lezcano A, Fernández García JM, Fernández Ramos C, Ferrández Longás A, LópezSiguero JP, Sánchez González E, et al. Estudio transversal español de crecimiento 2008. Parte II: valores de talla, peso e índice de masa corporal desde el nacimiento a la talla adulta. An. Pediatr. 2008; 68: 552-569.

9. Domingo-Salvany A, Regidor E, Alonso J, Alvarez-Dardet C. Proposal for a social class measure. Working Group of the Spanish Society of Epidemiology and the Spanish Society of Family and Community Medicine. Aten. Primaria. 2000; 25: 350-363.

10. Rasmussen KM, Yaktine AL. Institute of Medicine (US) and National Research Council (US) Committee to Reexamine IOM Pregnancy Weight Guidelines. Weight gain during pregnancy: Reexamining the guidelines. Washington, DC: National Academies Press (US); 2009.

11. Ministerio de Sanidad, Servicios Sociales e Igualdad. Informe anual del Sistema Nacional de Salud 2016. Gobierno de España, 2016. [Kontsulta: 2018-08-26]. Eskuragarri: http://www.mscbs.gob.es/estadEstudios/estadisticas/sisInfSanSNS/tablasEstadisticas/InfAnual SNS2016/Informe Anual SNS 2016 completo.pdf

12. Moschonis G, Grammatikaki E, Manios Y. Perinatal predictors of overweight at infancy and preschool childhood: the GENESIS study. Int. J. Obes. (Lond). 2008; 32: 39-47.

13. Larrañaga I, Santa-Marina L, Begiristain H, Machón M, Vrijheid M, Casas M, Tardón A, Fernández-Somoano $\mathrm{A}$, Llop $\mathrm{S}$, Rodriguez-Bernal CL, Fernandez MF. Socio-economic inequalities in health, habits, and self-care during pregnancy in Spain. Matern. Child. Health J. 2013; $17:$ 1315-1324.

14. Donkor HM, Grundt JH, Júlíusson PB, Eide GE, Hurum J, Bjerknes R, Markestad T. Social and somatic determinants of underweight, overweight and obesity at 5 years of age: a Norwegian regional cohort study. BMJ Open. 2017;7:e014548.

15. Bann D, Johnson W, Li L, Kuh D, Hardy R. Socioeconomic inequalities in childhood and adolescent body-mass index, weight, and height from 1953 to 2015: an analysis of four longitudinal, observational, British birth cohort studies. Lancet Public Health. 2018; 3: e194e203.

16. Boudet-Berquier J, Salanave B, Desenclos JC, Castetbon K. Sociodemographic factors and pregnancy outcomes associated with prepregnancy obesity: effect modification of parity in the nationwide Epifane birth-cohort. BMC Pregnancy Childbirth. 2017; 17: 273.

17. Weng SF, Redsell SA, Swift JA, Yang M, Glazebrook CP. Systematic review and meta-analyses of risk factors for childhood overweight identifiable during infancy. Arch Dis Child. 2012; 97: 10191026.

18. Ramsey PS, Schenken RS. Obesity in pregnancy: Complications and maternal management. In: UpToDate, Post TW (Ed) UpToDate. Waltham, MA, 2018 Apr. [Kontsulta: 2018-08-26]. 
Eskuragarri: https://www.uptodate.com/contents/obesity-in-pregnancy-complications-andmaternal-management

19. Druet C, Stettler N, Sharp S, Simmons RK, Cooper C, Smith GD, et al. Prediction of childhood obesity by infancy weight gain: an individual-level meta-analysis. Paediatr. Perinat. Epidemiol. 2012; 26: 19-26.

20. Erickson AC, Ostry A, Chan HM, Arbour L. Air pollution, neighbourhood and maternal-level factors modify the effect of smoking on birth weight: a multilevel analysis in British Columbia, Canada. BMC Public Health. 2016; 16: 585.

21. Dubois L, Ohm Kyvik K, Girard M, Tatone-Tokuda F, Pérusse D, Hjelmborg J, et al. Genetic and environmental contributions to weight, height, and BMI from birth to 19 years of age: an international study of over 12,000 twin pairs. PLoS One. 2012; 7: e30153.

22. Raleigh VS, Hussey D, Seccombe I, Hallt K. Ethnic and social inequalities in women's experience of maternity care in England: results of a national survey. J. R. Soc. Med. 2010; 103: 188-198.

23. Verret-Chalifour J, Giguère $Y$, Forest JC, Croteau J, Zhang P, Marc I. Breastfeeding initiation: impact of obesity in a large Canadian perinatal cohort study. PLoS One. 2015; 10: e0117512.

24. Txakartegi Etxebarria PX. Umearen pisu sobera: esku-hartzea lehen mailako arretako pediatrian. Doktore Tesia. UPV/EHU. Gurutzetako Unibertsitate Ospitalea, 2015-06-06. [Kontsulta: 2018-08-26]. Eskuragarri: https://addi.ehu.es/handle/10810/15960

25. Pereira-da-Silva L, Rêgo C, Pietrobelli A. The Diet of Preschool Children in the Mediterranean Countries of the European Union: A Systematic Review. Int J Environ Res Public Health. 2016; 13. Pii: E572.

26. Salcedo V, Gutiérrez-Fisac JL, Guallar-Castillón P, Rodríguez- Artalejo F. Trends in overweight and misperceived overweight in Spain from 1987 to 2007. Int. J. Obes. (Lond) 2010; 34: 17591765.

27. Txakartegi Etxebarria X, López Mateo M, Aurrekoetxea JJ. Obesidad y sobrepeso. Aproximación a la efectividad de una intervención sanitaria. An. Pediatr. (Barc). 2014; 80: 379-386. 
Iratxe Escudero Otxandorena, Eva Pereda-Pereda, Izaro Babarro Velez, Juan J. AurrekoetxeaAgirre 